\title{
Laparoscopic Cholecystectomy in Situs Inversus Totalis: A Case Report
}

\author{
Radomir Gelevski ${ }^{1}$, Gjorgji Jota ${ }^{2}$, Lazar Todorović3 ${ }^{3}$, Gjorgji Trajkovski², \\ Vladimir Joksimović́ ${ }^{2}$ Bojan Trenčić ${ }^{1}$ \\ ${ }^{1}$ General Hospital Kumanovo, Kumanovo, North Macedonia \\ ${ }^{2}$ University Clinic for Digestive Surgery Skopje, Skopje, North Macedonia \\ ${ }^{3}$ University Clinic for Paediatric Surgery Skopje, Skopje, North Macedonia
}

\section{SUMMARY}

Situs inversus totalis represents a rare autosomal recessive morphological anomaly of the internal viscera, equally affecting both genders. The genetic defect occurs in the $2^{\text {nd }}$ week of embryonic life, when a 270-degree clockwise rotation of the primitive digestive tube occurs. The incidence of calculosis of gallbladder in patients with situs inversus is the same as in the general population. A 61-year-old female patient with a history of four episodes of colicky, left hypochondrium and epigastric pain, without fever and jaundice, was admitted for elective laparoscopic cholecystectomy. CT of abdomen confirmed situs inversus totalis that was previously known to the patient. The patient was positioned in supine position and a mirror image configuration of the operating room was obtained, with surgeon and scrub nurse on the right side and assistant on the left side of the patient. Four trocars were introduced mirroring the standard position of the $5 \mathrm{~mm}$ trocars. During the dissection, second assistant was introduced for the laparoscope, due to the surgeon's limited motor skills in his left hand for delicate dissection, rendering him inapt to perform precise and safe dissection. The total operating time amounted to $\mathbf{1 1 0}$ minutes, which is three times longer than the standard operating time at our institution. The most critical point of the operation in constellation of situs inversus totalis is applying the clips, which requires precision and strength in the same moment. In the available literature, 40 open cholecystectomies before introduction of laparoscopy and 92 laparoscopic cholecystectomies were reported. To our knowledge, this is the first and the only reported laparoscopic cholecystectomy for situs inversus in North Macedonia.

Key words: situs inversus totalis, laparoscopic cholecystectomy, critical view of safety

Corresponding author:

Radomir Gelevski

e-mail: radomirgelevski@hotmail.com 


\section{INTRODUCTION}

Situs inversus totalis represents a morphological anomaly of the position of the internal viscera, that have a mirror image position to that of the general population. It is a rare autosomal recessive anomaly that equally affects both genders and could be associated with transposition cardiac anomalies, renal dysplasia and biliary atresia (1). It is believed that situs inversus totalis occurs as a genetic defect in the $2^{\text {nd }}$ week of embryonic life, when instead of the 270-degree counter-clockwise, a clockwise rotation of the primitive digestive tube occurs. The incidence of calculosis of gallbladder in patients with situs inversus is the same as in the general population.

The first case of laparoscopic cholecystectomy in a patient with situs inversus totalis was described by Campos and Sipes in 1991 (2).

\section{CASE REPORT}

A 61-year-old female patient was admitted at our department for elective laparoscopic cholecystectomy. The patient had a history of four episodes of left hypochondrium and epigastric pain that were exacerbated after fatty meals. The pain was colicky by nature, and there were no episodes of fever or jaundice. Laboratory evaluation demonstrated values within normal parameters. The patient had pre- vious knowledge of situs inversus and prior to admission, CT scan was obtained to verify the correct anatomy. Chest $\mathrm{X}$-ray revealed situs inversus without signs of bronchiectasis. CT of abdomen was performed and demonstrated situs inversus totalis, with liver and gallbladder on the left side. There were no signs of dilatation of intra- and extrahepatic bile ducts (Figure 1 and Figure 2).The patient was aware of her situs inversus prior to the admission and a written consent was obtained from the patient after the procedure and the risks of potential complications were explained in detail.

The patient was positioned in the supine position. The laparoscopic cholecystectomy was performed with the four-trocar technique, according to the American standard. A mirror image configuration of the operating room, designed for normal laparoscopic cholecystectomy, was achieved by placing the surgeon and the scrub nurse on the right side and the assistant on the left side of the patient. The monitor was placed on the left side, near the head of the patient. The patient was tilted head-end up and left side up, mirroring the standard position for laparoscopy. An $11 \mathrm{~mm}$ trocar was introduced through umbilical incision, and a $12 \mathrm{~mm} \mathrm{Hg}$ pneumoperitoneum was obtained. Another $11 \mathrm{~mm}$ trocar was introduced in the subxiphoid area. A $5 \mathrm{~mm}$ trocar was placed on the left midclavicular line and another $5 \mathrm{~mm}$ trocar was placed on the left anterior

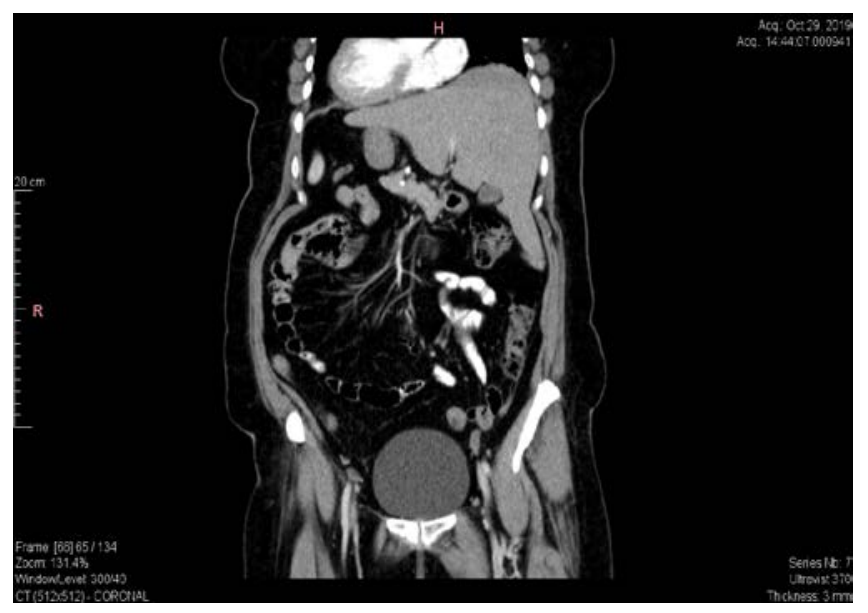

Figure 1. Contrast-enhanced CT of the abdomen, a frontal view

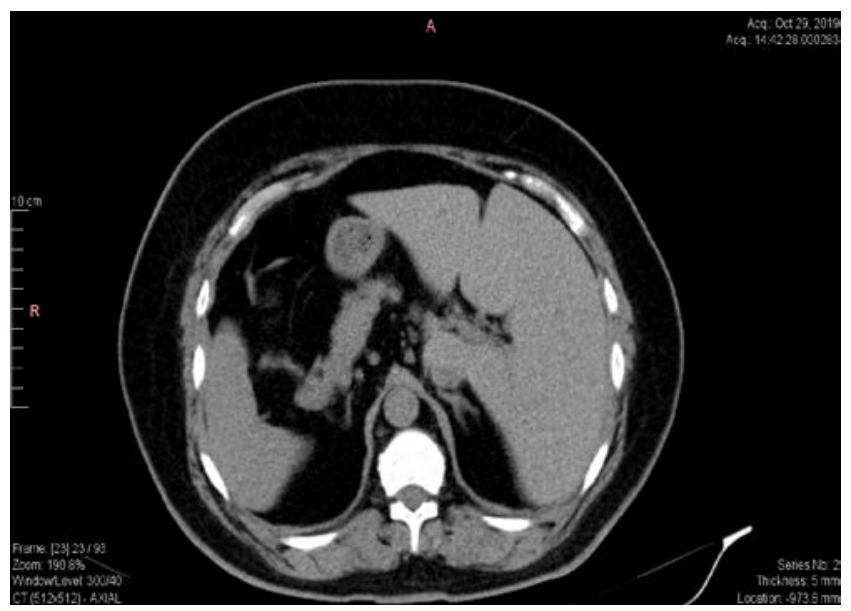

Figure 2. CT of the abdomen, a horizontal view 


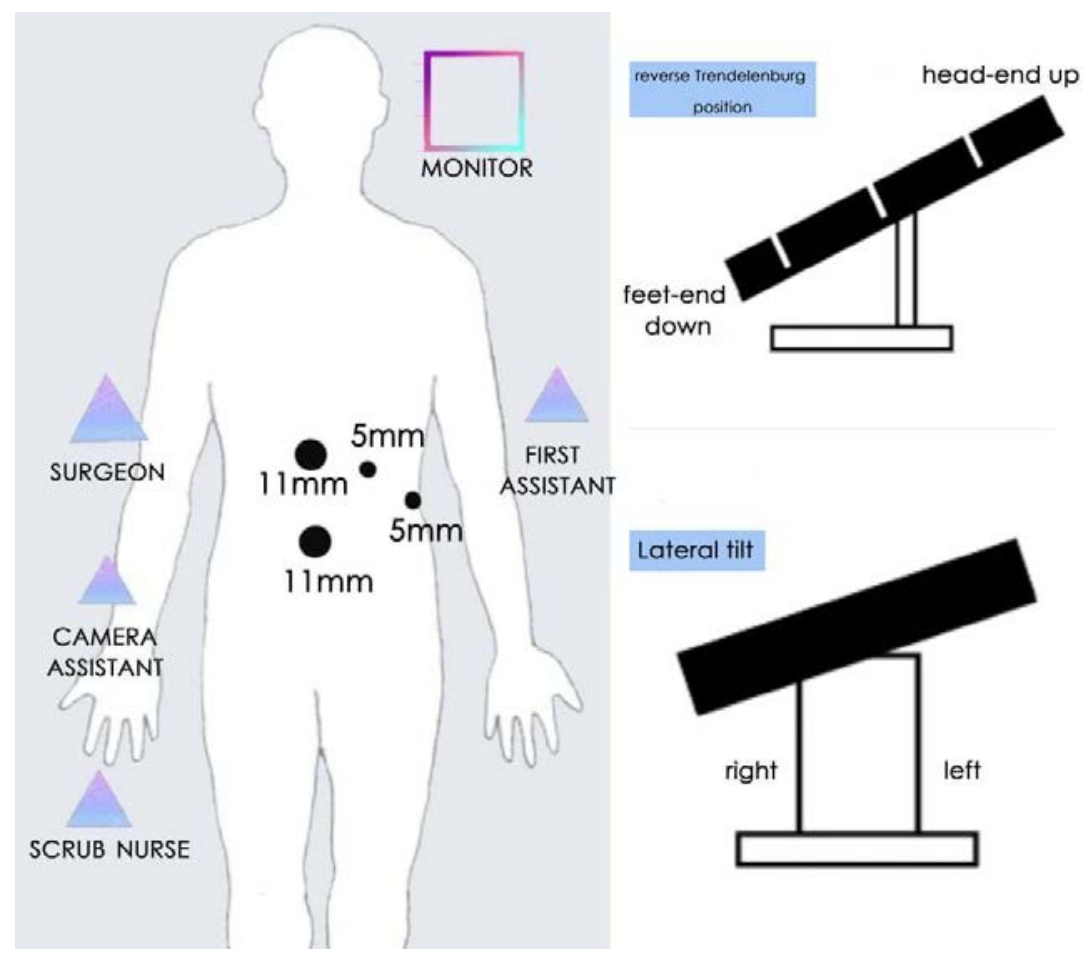

Figure 3. Mirror image organisation of the operating room
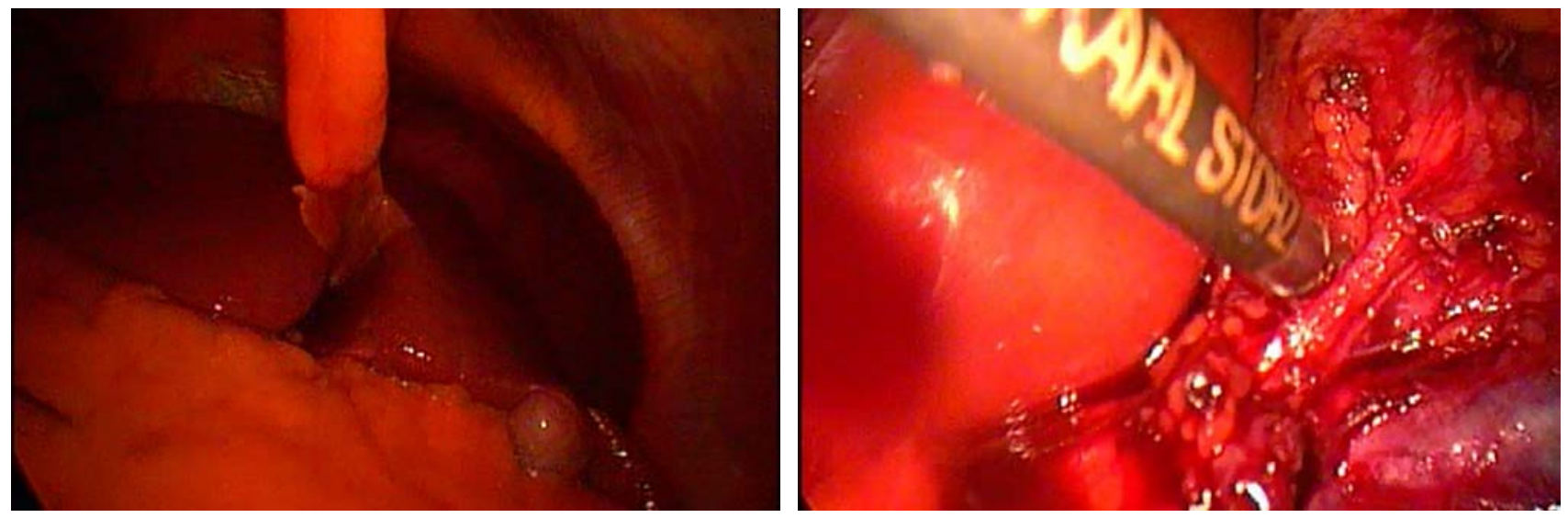

Figure 4. Laparoscopic exploration of abdominal cavity in situs inversus totalis (screenshot)

Figure 5. Dissection of Calot's triangle. Cystic artery (screenshot)

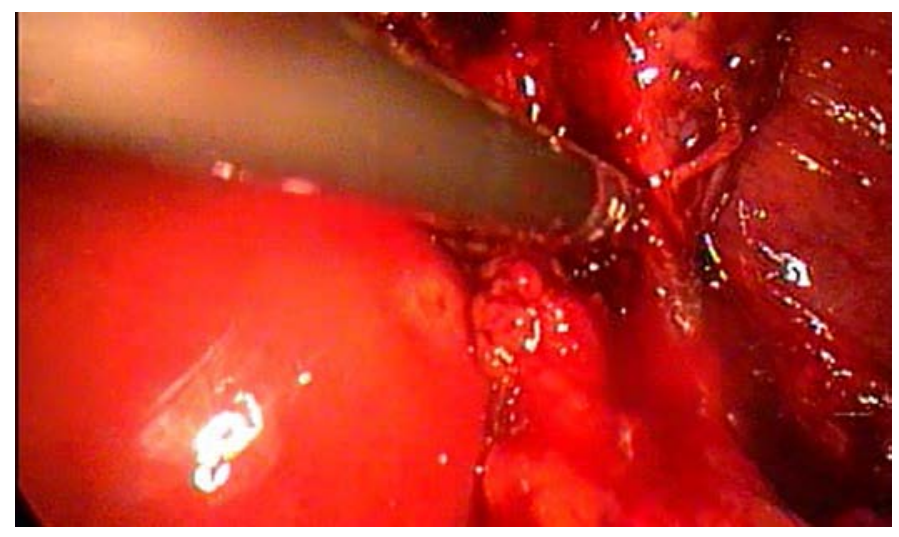

Figure 6. Dissection of Calot's triangle.Cystic duct (scereenshot) 
axillar line (Figure 3). Careful exploration of the peritoneal cavity was performed (Figure 4).

At the start of the operation, the surgeon was holding the laparoscope with the right hand and had a Kelly dissector in his left hand. The assistant grabbed the Hartman's pouch exposing the Calot's triangle (Figure 5 and Figure 6). Both the operator and the assistant were experienced surgeons with more than 1,000 laparoscopic cholecystectomies each. The operator was right-handed, with very limited motor skills in his left hand for delicate dissection, which rendered him inapt to perform precise and safe dissection. At this point, the decision was made to introduce a second assistant, to manipulate the laparoscope, so that the surgeon can use his right hand for dissection. Critical view of safety was obtained by dissecting the fatty tissue on the posterior side above the Rouviere's sulcus plain, through the subxiphoid port. After skeletonization of the cystic duct and the cystic artery was performed, ML clips were applied, and the structures divided. The dissection from the liver bed was uneventful and the gallbladder was retrieved via the umbilical port.

The total operating time was 110 minutes. The patient was discharged the following day.

\section{DISCUSSION}

Situs inversus totalis does not increase the predilection for gallbladder disease (1) nor implies higher probability of existence of anatomical malformation of the biliary tract than in the general population. It constitutes a diagnostic problem because of the location of pain. In the majority of patients, the pain is localized in the upper left quadrant, and only in $10 \%$ of the cases patients complain of an upper right quadrant pain (2), suggesting that central nervous system did not follow the transposition.

The most difficult part of the dissection in situs inversus totalis is that it gives privilege to lefthanded or ambidexter surgeons. In case of a righthanded surgeon, his motor skills can be insufficient for precise dissection and obtaining critical view of safety. The most critical point of the operation in this constellation is to apply the clips, which requires precision and strength in the same moment (3).

There are no data that show difference in conversion to open surgery rate in the available litera- ture. This should be taken with precaution. In the available literature, there are 40 reported open cholecystectomies in situs inversus totalis before introduction of laparoscopy, and 92 reported laparoscopic cholecystectomies (4). The number of performed laparoscopic cholecystectomies in situs inversus totalis is modest and the conversion to open rate should be subject of further discussions.

Situs inversus totalis was known to the surgeon prior to the operation and careful consideration was given to all aspects of the procedure. To our knowledge, this is the first and the only operation performed in North Macedonia until now and there was no previous professional and institutional experience. The patient was made fully aware of the situation, and an informed consent was obtained for the procedure that was going to be conducted for the first time. Both the surgeon and the assistant were experienced surgeons with more than 1,000 laparoscopic cholecystectomies each. When surgeon's inability to perform the dissection skilfully and precisely with his left hand was established, we were faced with the decision how to proceed with the operation. There were several options available and discussed prior to the operation:

1. to position the surgeon between the legs of the patient in the Lloyd-Davis position;

2. to have the assistant to manipulate the laparoscope;

3. to delegate the operation to a left-handed or ambidexter surgeon (not available at our institution); or

4. to introduce a second assistant for the laparoscope.

Our operating time was 110 minutes, which is three times longer than the standard operating time at our institution. Confronting a new, unusual orientation demands adaptability and manual dexterity to cope with the intraoperative situation (5). There are no available data to indicate increased risk of bile duct injuries (6).

\section{CONCLUSION}

Laparoscopic cholecystectomy, although technically challenging, can be safely performed and is regarded as golden standard for treatment of cholelithiasis in patients with situs inversus totalis. 


\section{References}

1. Goyal S, Garg A, Singla VK. Laparoscopic cholecystectomy in situs inversus totalis: Two case reports with review of the literature. Arch Med Health Sci 2015;3:272-8 https://doi.org/10.4103/2321-4848.171921

2. Salama IA, Abdullah MH, Houseini M. Laparoscopic cholecystectomy in situs inversus totalis: Feasibility and review of the literature. Int J Surg Case Reports 2013;4:711-5 https://doi.org/10.1016/j.ijscr.2013.02.030

3. Oms LM, Badia JM. Laparoscopic cholecystectomy in situs inversus totalis: The importance of being left handed. Surg Endosc 2003;17(11):1859-61 https://doi.org/10.1007/s00464-003-9051-7
4. AlKhlaiwy O, AlMuhsin AM, Zakarneh E. Laparoscopic cholecystectomy in situs inversus totalis: Case report with review of techniques. Int J Surg Case Rep 2019;59:208-12 https://doi.org/10.1016/j.ijscr.2019.05.050

5. Kumar S, Fusai G. Laparoscopic cholecystectomy in situs inversus totalis with left-sided gallbladder. Ann R Coll Surg Engl 2007;89:1-3 https://doi.org/10.1308/147870807X160461

6. Yaghan RJ, Gharaibeh KI, Hammori S. Feasibility of laparoscopic cholecystectomy in situs inversus. J Laparoendosc Adv Surg Tech 2001;11:233-7 https://doi.org/10.1089/109264201750539763 


\title{
Laparoskopska holecistektomija kod situs inversus totalis anomalije: prikaz slučaja
}

\author{
Radomir Gelevski¹, Gjorgji Jota², Lazar Todorović ${ }^{3}$, Gjorgji Trajkovski², Vladimir Joksimović \\ Bojan Trenčić ${ }^{1}$ \\ ${ }^{1}$ Opšta bolnica Kumanovo, Kumanovo, Severna Makedonija \\ ${ }^{2}$ Univerzitetska klinika za digestivnu hirurgiju Skoplje, Skoplje, Severna Makedonija \\ ${ }^{3}$ Univerzitetska klinika za pedijatrijsku hirurgiju, Skoplje, Skoplje, Severna Makedonija
}

\section{SAŽETAK}

Situs inversus totalis predstavlja retku, autozomno recesivnu, morfološku anomaliju pozicije unutrašnjih organa, koja jednako obuhvata oba pola. Genetski defekt nastaje u drugoj nedelji embrionalnog razvitka, kada nastaje rotacija primitivne digestivne cevi za 270 stepeni u pravcu kazaljki časovnika. Incidencija kalkuloze žučne kese kod bolesnika sa situs inversus totalis anomalijom ista je kao u opštoj populaciji. Šezdesetjednogodišnja bolesnica sa anamnezom 4 epizode kolika u levom hipohondrijumu i epigastrijumu, bez groznice i žutice, primljena je na kliniku i urađena je elektivna laparoskopska holecistektomija. CT abdomena potvrdio je situs inversus totalis anomaliju, sa kojom je bolesnica bila prethodno upoznata. Bolesnica je bila postavljena u supiniranu poziciju i postavljen je odraz operacione sale u ogledalu, sa hirurgom i instrumentarkom sa desne strane $i$ asistentom sa leve strane bolesnice. Postavljena su 4 troakara kako bi dala odraz u ogledalu standardne pozicije troakara od $5 \mathrm{~mm}$. Tokom disekcije, pozvan je drugi asistent zbog primene laparoskopa, kao rezultat ograničenih motornih veština operatora u levoj ruci za delikatnu disekciju, što ga je činilo nedovoljno adekvatnim za izvođenje precizne i sigurne disekcije. Ukupno vreme operacije bilo je 110 minuta, što je tri puta duže od standardnog trajanja operacije u našoj instituciji. Najkritičnija tačka operacije u konstelaciji situs inversus totalis anomalije je aplikacija klipsi, koja zahteva istovremeno preciznost i snagu. U dostupnoj literaturi, opisano je 40 otvorenih holecistektomija i 90 laparoskopskih holecistetomija. Prema našim saznanjima, ovo je prvi i jedini opisani slučaj laparoskopske holecistektomije u Severnoj Makedoniji.

Ključne reči: situs inversus totalis, laparoskopska holecistektomija, kritičan ugao bezbednosti 